UDK 355.02(497.11)

doi:10.5937/bastina1947117G

Miodrag L. GORDIĆ*

Originalni naučni rad

Faculty of International Politics and Security,

University “Union - Nikola Tesla”, Belgrade

Ivan B. PETROVIĆ **

Military Academy, University of Defence, Belgrade

\title{
MODEL OF MILITARY NEUTRALITY AS PERSPECTIVE OF DEVELOPMENT OF THE REPUBLIC OF SERBIA***
}

\begin{abstract}
Neutrality, from the aspect of the defence of the country, implies, primarily, relying on its own strengths. A military neutral country must neither be a member of a military alliance nor participate in an armed conflict as a warring party, unless it is selfdefence, but also to promote and encourage peace processes. On the other hand, political neutrality should exclude membership in political organizations that represent particular interests or the creation of other formal political alliances that exclude the independent conduct of country policy. The economy of small countries through the concept of neutrality can directly contribute to improving security, and economic relationships with the world can be used to strengthen friendship and improve connections between countries. Bearing in mind the constant changes in international relations at the global level, as well as the complex security environment of the Republic of Serbia, military neutrality carries with it certain risks and advantages. From the security point of view, the Republic of Serbia must provide the equipping of an army with modern weapon systems in accordance with the threats to security. This is the only way it can be a factor of deterring possible military threats, but also a guarantor of unhindered economic development of the country and protection of vital economic and infrastructural investments, as a prerequisite for economic investment in the Republic of Serbia. On the other hand, the military neutrality of the Republic of Serbia makes it easier to engage in significant projects such as the new 'Silk Road', which is a consequence of its neutrality in tight relations between China and the United States, as the main leverage of the NATO, but also other initiatives, such as the renewal of co-operation with countries which made up the Non-Aligned Movement. From this, a direct conclusion is drawn that neutrality, as a means and policy instrument, more or less represents a flexible constant of the foreign policy of the Republic of Serbia.
\end{abstract}

Key words: BRI, CEEC $16+1$, Air Force and Air Defence.

* associate profesor, gordicmiodrag@gmail.com

** docent, ivanpetrovic1977@gmail.com

*** This paper is the result of the project number VA-DH/3/17-19 "Calculation of Long-term Financial Sustainability of the Duty Forces of Air Defense System of Serbian Armed Forces in Performing the Airspace Control and Protection in Peace". The project is funded by the Ministry of Defence of the Republic of Serbia. 


\section{HISTORY OF THE DEVELOPMENT OF NEUTRALITY}

Neutrality as a term dates back from the old age, and during that historic period, there were also countries that did not want to interfere in third-country conflicts. In the Middle Ages, neutrality was primarily concerned with the possibility of trade with the countries in conflict, without interfering in the conflict itself. The concept of military neutrality in modern terms was developed by Switzerland. Switzerland is the first country to ban passage of foreign troops through its territory and recruitment for wars in which it was not included (Novaković 2011). Considering the conducted legal regulations of Switzerland, the participating countries of the Vienna congress in 1815 recognized its military neutrality (Đurašinović-Radojević 2016). This event significantly influenced the development of military neutrality around the world. Significant progress in the legal definition of military neutrality was created by the adoption of the Paris Declaration of the Maritime Law of 1856, which prohibited piracy (Jončić 2016).

Neutrality, in the sense of international law, means the non-participation of the country in a war with other countries, that is, abstaining from certain acts, primarily from the warfare, and then from some other acts that, in certain historical periods, are considered incompatible with neutrality. An essential feature of this non-participation is impartiality and reciprocity. Consequently, neutrality can be interrupted either by the neutral state itself or by one of the warring parties. Both can be challenged or not. With the emergence of a state of neutrality, the rules of neutrality begin to apply to all sides-warring and neutral. These rules change the right of peace only in certain parts (Grlić-Radman 2003). Neutrality can also be defined as an impartial position of the country that does not participate in any armed conflict and that neutrality is recognized by other countries (Krivokapić 1998).

The most important document defining neutrality in a specific armed conflict is the Hague Convention adopted V in 1907, which is based on the legal status of Switzerland. Convention V (Convention on the rights and obligations of neutral forces and persons in war on land) was devoted to the issue of neutrality in the case of war on land, and it was also defined by a neutral person as a citizen of a non-participating country. Presently, this document continues to be a key reference point for the fundamental rights and obligations of neutral states during an armed conflict, which is reduced to the following:

- Territory of neutral countries is inviolable;

- The parties in the conflict are prohibited to use the territory of neutral states for the transport of troops and military equipment;

- The parties in the conflict are prohibited to use the territory of neutral states for mobilization of troops. 
Furthermore, from the country that has declared itself neutral in a particular armed conflict, it is expected to be impartial during conflicts against all warring parties, regardless of its own dominant values and ideological orientation. However, the neutral country is not obliged to have trade and economic relations at the same level with all countries, or to be impartial in ideological matters.

Convention XIII (Convention on the rights and obligations of neutral forces and persons in war at sea) concerned the question of neutrality in maritime warfare. The right of neutrality explicitly does not regulate the issue of the air war, since it was not counted against the circumstance of totalitarianization of the modern war, although the question remains whether the reason for this is to observe the concept of neutrality by a relic of the past that has lost or at least changed its meaning in contemporary tendencies, or this issue has deliberately remained undefined in order to facilitate its constant violation in other countries (usually small and/or neutral), unannounced and without permission, as a legally unregulated area that leaves the possibility of illegal interventions in the form of bombing with or without land invasion of other countries (Bosnia and Herzegovina, Federal Republic of Yugoslavia, Iraq, Syria, Libya, Lebanon, etc.) or delivery of weapons and other military equipment with misuse of delivery of humanitarian aid (the case of the delivery of weapons to the former Yugoslav republics: "The case of Martin Spegelj", the air corridors of the "occupied" Sarajevo and the direct delivery of arms by Western countries to the Muslim and Croat sides - Operation "Bljesak" and "Oluja").

The Hague rules were applied automatically after the commencement of the war, both to the parties of the war, and to all countries that were not involved in the conflict, due to the obligations of all countries that do not participate in the conflict in order to respect the rules of neutrality. According to the Hague norms, a neutral country is obliged not to assist the warring parties, not supplying them with weapons or soldiers, and not allowing them to use their territory. Also, warring parties must respect the inviolability of the territories of neutral countries. Neutral countries do not have to regulate their trade or economic relations with warring parties in a unique way. Also, they do not have obligation to be impartial in ideological matters. In essence, Hague rules have retained their validity to this day.

Over time, three concepts of neutrality were singled out:

1. Permanent neutrality - position of a country which has committed itself in every war remain neutral, and where other states are obliged to respect its neutrality. For permanent neutrality, there is not enough one-sided statement (for example: Iceland, 1918) or government's announcement that it will pursue a policy of neutrality (Sweden or Ireland and Finland in the last few years), although such a statement can affect the final result. It should also be noted 
that neutral countries most often seek permanent confirmation of their status through the promotion of peace and dialogue. They are often the initiators of peace initiatives and regularly participate with their troops in peacekeeping missions. The role of these countries as mediators among the warring parties was also noticed. The foundation of permanent neutrality was set by Cyril Black in his conclusions that the neutral country should:

- Avoid engaging in warfare;

- Enhances national defence resources;

- Leads an external policy that avoids potential military engagement, videlicet the policy of "abstaining" (Krivokapić 1998).

2. Neutralism - the term was created at the beginning of World War I during the internal debate in Italy over the participation in the War. However, this term gets full meaning during the Cold War and means that the country is not willing to belong to any military alliance. This term was mainly used by former colonies in foreign policy (most of these countries later joined the Non-Aligned Movement).

3. Non-alignment - this term refers to countries that are not in any alliance, which did not want to be involved in the conflict of East and West. Through the Non-Aligned Movement, these countries formally advocated a non-aligned, disarmament policy, the completion of the decolonization process, and a radical transformation of international relations. On the other hand, membership in this movement did not obligate the country to participate in armed conflicts that are not related to the Cold War, even among themselves. For example, one of the founding countries of the movement, India, fought several times with China and Pakistan (Boczek 1989).

In essence, the military neutrality of the Republic of Serbia corresponds with the first and third model of neutrality with its legal regulations and political attitudes. Similarly, the Swedes define their status as "non-alignment during peace and neutrality during a state of war".

In relation to the possibility of origin, there are two types of neutrality: freely chosen and neutrality by foreign determination. For foreign determination of neutrality, the term of neutralization is also applied. The freely chosen permanent neutrality can be one-sided (the state itself declares neutrality without international recognition) or internationally recognized. Both freely chosen, as well as neutrality by foreign determination (Belgium 1831), can be guaranteed by other superpowers. Integral or absolute neutrality means the complete application of neutrality. This type of neutrality represents the 20th century. Unlike absolute neutrality, differential neutrality implies the participation of neutral country in economic, but not in the military sanctions of a collective security community (for example: League of Nations, United Nations, etc.) against the aggressor. 
According to Stajic-Radivojevic-Mirkovic (2016), in the strategic decision on the issue of neutrality, it is necessary to answer the following questions:

1 . How to ensure neutrality?

2. From which will neutrality depend?

3. Whether neutrality must be formally confirmed by interested (super) powers?

4. Is neutrality possible in certain geopolitical frameworks and in the conditions of regionaland world war?

5. Does neutrality mean it is not necessary to prepare for war?

6. What is the relationship between neutrality and the National Security Strategy?

7. Does neutrality limit cooperation with other forces and military alliances?

8. How legally in the international community to protect its own neutrality if it is violated by some superpowers?

\section{IDEOLOGICAL BACKGROUND OF NEUTRALITY}

From the point of view of countries directly affected by war destruction, neutral countries are regarded as privileged during the war period, while during peacetime they usually play the role of moderator among the spoiled parties. However, neutrality cannot be hindered by the different blackouts and compromises that the neutral state must endure during war conflicts. This can be seen on the example of Switzerland during, and especially after the World War II. Due to the absence of the principle of neutrality of Switzerland during the World War II, the idealized picture of its neutrality was being shaken in the public for decades, and many authors in modern analyzes directly charge that Switzerland's behavior prolonged the end of the war (Ziegler 1992, 1998; Wittmann 1998; Brunner 2000). The period from 1945 to 1952 was abundant by pressures on neutral states by the United States (Fišer 2013). During this period, Sweden and Switzerland were required to give up their interpretations to neutral politics and to accept American hegemony. According to Štavljanin (2013), the positive neutrality, as recognized by the UN 1995, did not prevent Turkmenistan from cooperating with the US (the Partnership for Peace program, enabling US aviation to build bases on the territory of Turkmenistan with the aim of supplying troops in Afghanistan), Russia (Associated Member of the Commonwealth of Independent States) and China and Iran (capital investments, gas pipeline and energy program), as well as the EU (Nabucco). There are various mechanisms that can affect the status of a neutral country, such as: trade agreements, energy, the availability of new weapons and technologies, etc. For example, membership in the "Partnership for Peace" implies the signing of bilateral agreements with NATO. 
The neutrality rules also did not define new forms of violence such as: asymmetric security threats, which main characteristic is transnationality, subversion, economic and political blackmail, terrorism and crime of transcontinental dimensions. On the economic front, the growth of interdependence and the development of the global economy, forcing the countries to be more open to the outside world. This is in line with the trend of declaring neutrality as an unsuitable concept and the person of non grata in international relations and in the legal and political scene. Solidarity and cooperation among the partner countries is used as an excuse for the lost national identity and sovereignty. According to Herch Lauterpacht, where is more collective security there is less neutrality, and vice versa. As the key term of statehood is sovereignty, neutrality is irreversibly connected with the sovereignty of each country. Neutrality is originally conceived as an instrument for protecting independence and neutrality does not imply isolation. It is not constant, it is subject to change imposed by political circumstances and technological advancement. Also, in general terms, it represents freedom of choice on the individual's agenda. Neutrality allows the individual to express his own views.

\section{POLITICAL NEUTRALITY OF SMALL COUNTRIES - CASE OF THE REPUBLIC OF SERBIA}

There are different approaches in defining the term of small states. Usually, the capacity and strength, ie the quantitative and qualitative characteristics, are used as the starting points for defining. The quantitative definition of the term of small countries is considered from the geographic, demographic and economic aspect. From the geographical aspect, the area of small country is less than $200000 \mathrm{~km}^{2}$. From demographic aspect, small countries have fewer than 15000000 inhabitants. From an economic point of view, defining the state takes into account the economics and economic potential, ie the gross domestic product. Thus, small countries have a limited territory and a relatively small population and limited resources (Gordić-Petrović 2014). The qualitative definition of the small countries, in addition to quantitative indicators, also takes into account some relative indicators of the size. These indicators can be internal (political will - initiative, national interests, internal security situation, economic situation, relations with neighbors) and external (geostrategic position, strategic partners, membership in international organizations, membership in military alliances).

The research of international relations in the last hundred years points to a general trend of changes in the international order reflected in: reducing the total number of leading, or superpowers; increasing the number of middle and 
small countries, and deepening differences in potentials (military, economic and other) between the first and second groups of them (Gaspar 2007).

According to Hey, the characteristics of small countries are as follows:

- Low involvement in world politics and limited operation in a direct geographic environment;

- A relatively small number of international topics that are relevant to them;

- The application of diplomatic and economic instruments, rather than military instruments;

- Insisting on the "moral aspects" of international relations, such as international law, principles, etc;

- Focus on multilateral co-operation and multilateral organizations;

- Taking neutral attitudes;

- Reliance on superpowers for the purpose of protecting and securing resources;

- A focus on co-operation in order to avoid conflict;

- Above average spending resources in order to ensure the physical and political security and the "survival" of the country.

According to Morgenthau (1948), "small countries have based their independence on maintaining the balance of power with neighboring countries, the existence of a superpower-patron or lack of attraction for conquering ambitions". Also, to these considerations it can be added one more: the foreign policy of small countries is generally reactive rather than proactive. These countries do not trigger global change or important events, they usually respond to them.

The neutrality of a state depends on its foreign policy, which should be aimed at promoting peace and co-operation and sending troops into peacekeeping missions. A good relationship with military-political alliances and reliance on four pillars of foreign policy (US, China, Russia and India) should open the possibility for the Republic of Serbia to develop not only good military but also political and economic relations all around the world.

Small countries cannot control the security environment. They have to be ready to adapt their security doctrines to changes in the environment. It should be noted that a strategic culture can be defined as a set of beliefs, attitudes and norms related to the use of military force. Strategic culture is primarily aligned with historical experience. Bearing in mind the aforementioned, a good strategy is the one that creates the greatest possible maneuvering space, and the freedom of action to choose between different alternative policies.

An example of balancing between different alternative policies in a historical context is the affiliation of Serbia (then within the SFRY) to the Non-Aligned Movement (Table 1). Bogetić (2013) believes that it is not yet clear whether 
this policy was actually desired or extorted, and why did Yugoslavia move away from Europe and tied it to distant and unknown civilizations.

Table 1. Characteristics of neutral VS of non-aligned countries by Bogetić (2013)

\begin{tabular}{|c|c|}
\hline NEUTRAL COUNTRIES & NON-ALIGNED COUNTRIES \\
\hline 1. mainly European countries & mostly former colonies \\
\hline $\begin{array}{l}\text { 2. mediators between East } \\
\text { and West and initiators of } \\
\text { compromise solutions }\end{array}$ & $\begin{array}{l}\text { mediators between East and West and initiators } \\
\text { of compromise solutions }\end{array}$ \\
\hline $\begin{array}{l}\text { 3. declarative neutrality with } \\
\text { secret concessions to the } \\
\text { Atlantic or Warsaw Pact }\end{array}$ & $\begin{array}{l}\text { the engaged approach and the open support of } \\
\text { the parties to the conflict, which (according to } \\
\text { the non-aligned countries) opposes aggression } \\
\text { and contributes to the preservation of peace } \\
\text { in the world, and at the same time, condemns } \\
\text { those parties in a conflict that is threatening } \\
\text { international peace and security }\end{array}$ \\
\hline $\begin{array}{l}\text { 4. they advocate the preservation } \\
\text { of the status quo or for certain } \\
\text { reforms that do not affect the } \\
\text { existing international order }\end{array}$ & $\begin{array}{l}\text { the establishment of a new international } \\
\text { economic order that would enable to be } \\
\text { bridged the gap between the rich North and } \\
\text { the poor South and the elimination of the } \\
\text { tendencies "that the rich become richer and the } \\
\text { poor become poorer" }\end{array}$ \\
\hline $\begin{array}{l}\text { 5. in order to achieve the status } \\
\text { of permanent neutrality, in } \\
\text { addition to the unilateral } \\
\text { declaration of the country, } \\
\text { international consent is } \\
\text { required expressed in the } \\
\text { appropriate international } \\
\text { legal form }\end{array}$ & $\begin{array}{l}\text { the non-alignment, as an individual foreign } \\
\text { policy determination of individual states, is not } \\
\text { regulated by legal norms or implies the consent } \\
\text { of superpowers }\end{array}$ \\
\hline
\end{tabular}

6. occurs at the beginning of the occurs in the middle of the XX century XIX century (permanent)

7. absence of a higher degree of a significant number of non-aligned countries synchronized action and their links within the Non-Aligned Movement

Geographic, demographic and economic factors of geostrategic position classify Serbia into small countries. In correlation with many other factors that Serbia cannot influence, these facts play a key role in the selection of an adequate 
security commitment of the Republic of Serbia. As a small country with modest resources, the Republic of Serbia must be aware that by biological harm in the XX century, it has made several wrong estimates and wrong strategic decisions. Any strategic decision in the field of security is also fateful for the future of the people and the country. Therefore, the condition of overall progress (viewed through the prism of geopolitical and geostrategic relations) is a continuous review of national interests and strategic decisions in the context of overall social development (Gordić-Petrović 2014).

\section{MILITARY NEUTRALITY OF THE REPUBLIC OF SERBIA}

The Republic of Serbia proclaimed the military neutrality for the first time on November 27th 2007 by adopting the Resolution on the Protection of Sovereignty, Territorial Integrity and the Constitutional Order of the Republic of Serbia in the National Parliament of Serbia. The Article 6 of the Resolution reads as follows: Due to the overall role of NATO, from the illegal bombardment of Serbia without a Security Council decision to Annex 11 of the rejected Ahtisaaris' plan, which determines that NATO is "ultimate supervisory authority" in an "independent Kosovo", the National Assembly hereby declares the neutral status of the Republic of Serbia towards effective military alliances until a referendum is called, at which the final decision on this issue will be made.

This resolution was a reflection of the lack of a coherent policy towards Kosovo and Metohija of all relevant political factors in the country, and resolution was not a consequence of realistic aspirations of the Republic of Serbia for military neutrality. As an obvious example that confirms this conclusion, there are also amendments to the Defence Law of 2018, in which military neutrality is not even mentioned. This law defines "military neutrality and co-operation and partnership with countries and international organizations in the field of security and defence" as a defensive interest. An attempt by one part of the MP to adopt the Law on Military Neutrality in the Assembly in 2017 was also unsuccessful.

In the drafts of the National Security Strategy and the Defence Strategy (still documents valid in 2009), military neutrality is defined as Serbia's strategic orientation. The concept of neutrality is defined as a proactive and dynamic model of enhancing co-operation with military and political alliances, and not as an isolationist act, as seen by some of the advocates of Serbia's accession to the NATO alliance. They believe that the lack of foreign policy strategy and the contradictory catch-all foreign policy of Serbia are the cause of both the unclear and unpredictable security policies of Serbia (Radoman 2016). 
The issue of Euro-Atlantic integrations was not perceived as a problem until the process of negotiations on the Status of Kosovo under the UN's special envoy Marti Ahtisaari in 2006. After Serbia's proposal for settlement was rejected by the Kosovo Albanians, Serbian representatives took a more hard line approach. When Marti Ahtisaari came out with his Status Settlement Proposal (so-called Ahtisaari Plan), that foresaw Kosovo as independent state from Serbia, the ruling coalition started to directly accuse NATO to be a protector of Kosovo separatism. The effect was that the Government began the process of rapprochement with Russia and China, in order to prevent the recognition of Kosovo in the UN Security Council. Their opinion is that the "neutrality" of Serbia represents just a political move that has fulfilled (or still does) its purpose. And that purpose has its domestic and foreign function. Domestic function is to create a political cleavage based on negative sentiments towards NATO, thus to create a pool of support for parties that employ more or less anti-Western discourse. Foreign function is to keep Serbia out of NATO as a sort of a revanchist move, due to the issue of Kosovo. And of course, in this way, the political elite tried to secure continuous support of Russia, which is opposing any further enlargement of NATO (Novaković 2012).

However, Serbia has not given up its membership in some new military alliances, but only memberships in the ones that currently exist. Also, the presence of foreign troops in the territory, as well as their movement and the construction of military bases, are not forbidden. On December 14th, 2006, Serbia became a member of the "Partnership for Peace" program, and then it was started the process of institutional co-operation with NATO. In accordance with the pronounced neutrality, the Republic of Serbia realizes a large number of military exercises with NATO, but also with ODKB, as well as bilateral exercises (for example: "Air solution" with the Republic of Romania). Presently, Serbia has signed bilateral military co-operation agreements with more than 60 countries, including close co-operation with Ohio National Guard, western countries, the NATO, etc. However, the domestic advocates of Serbia's entry into NATO a special thorn in the eye, presents the SerbianRussian Emergency Situations Center, which was established in Nis 2012, based on the agreement signed in 2009. The Center was established to support the development of a humanitarian response to emergencies in Serbia and other Balkan countries. So far, Russian planes have participated in several actions to extinguish the fire in the Balkans. During the May floods in 2014, Russia received aid, and the participation of Russian rescuers was also significant. The suspicious attitude towards Serbia in NATO, unlike other European countries that have accepted the concept of neutrality is generally explained by the fact that in cultural terms they have always been considered part of the Western civilization and from the NATO perspective they are friendly 
countries. Furthermore, these are rich countries that can finance their neutrality (Litavski 2012). According to Brkić (2009), one of the basic ideas for the establishment of the NATO is contained in Article 2 of the Washington Agreement (the Founding Act of NATO), which is focused on economic and social development within the Alliance. He added that the criteria for assessing the readiness of a country to join NATO are political and economic rather than military.

\section{MILITARY NEUTRALITY OF SMALL COUNTRIES - THE CASE OF THE AIR FORCE AND AIR DEFENCE OF THE REPUBLIC OF SERBIA}

Neutrality is a defensive act that small or weaker countries have in conflict situations, and one of the main principles of military neutrality is the right to self-defense. The country that aspires to be militarily neutral must have a respectable security system. The organizational and technological improvement of military capabilities is based on equipping the armed forces with new weapons and equipment systems. Military neutrality allows the state to create the origin of new weapons procurement on the basis of potential security risks. However, military neutrality is extremely expensive for any country, especially if it wants to achieve a required level of security in relation to the environment. Military neutrality should imply a better position for the Serbian defence industries, but in practice, due to the restrictive military budget, the deployment of the military inventory of the Army of Serbia is very slowly. It can be said that in the last 25 years no defence budget has been developmental. The management of the defense industry must carefully follow the current trends in the world market, because the domestic market is very small in terms of traffic and cannot provide the desired profit.

Strengths, weaknesses, opportunities and threats of equipping with the arms of eastern production (in terms of equipping with the People's Republic of China or the Russian Federation) can also be researched by SWOT analysis. SWOT analysis represents the method of strategic management, which in analytical way sets the basis for decision making on strategic options and developmental behavior of the organization (Terry, 1997). The basic idea of SWOT analysis is reflected in providing the conceptual framework for the selection of strategic options, linking internal factors (strengths and weaknesses) and external factors (opportunities and threats) functioning of the organization. SWOT analysis of Air Force and Air Defence equipping with weapon systems (multirole combat aircraft, anti-aircraft missile system, radars and unmanned aerial vehicles) of eastern production is shown in Table 2. 
Table 2. SWOT analysis of Air Force and Air Defence equipping with weapon systems of eastern production

\section{S (Strengths)}

Compact radar field in the airspace of the country at access points, strategic regions and facilities with lower and upper boundary of detection defined by technical characteristics of radars.

Transfer and display surveillance data in real time.

Tactical radius that provides timely interception of enemy aircraft over the national territory.

Shorter flight time from readiness on the ground.

Quality co-operation between Air Force and Air Defence and the Army Force during the performing of the air support tasks.

Successful integration of modern medium and low range anti-aircraft missile systems.

Effective destruction of aircraft and aviation assets of new technological generations.

W (Weaknesses)

Absence of interoperability with Air Force and Air Defence of neighboring countries and NATO.

Poor knowledge of Russian and Chinese language for the needs of training a large number of members of Air Force and Air Defence on new weapons and equipment systems in the Russian Federation and China.

Retraining soldiers who work on assets of western production (primarily on the radar AN-TPS70).

\section{O (Opportunities)}

Compatibility of the largest part of the existing weapon and equipment system with new weapon systems and equipment does not require higher investment infrastructure costs. Compatibility with existing weapon systems will facilitate the implementation of higher levels of maintenance on new weapon systems and equipment.

Possibility of involving cooperating firms in the maintenance of new weapons and weapon systems and significant strengthening of the military industry and the overall economic development.

Long-term financial sustainability of equipping through the re-channeling of part of the revenues from the performing of the air traffic control and protection task.

Simplified transfer of knowledge and technology.

Equipping weapon systems with proven allies reduces the possibility of diversion and destruction of units.

\section{T (Threats)}

Difficult provision of assistance to aircraft in emergency situation in accordance with regional co-operation in the field of air traffic control.

Inability to adopt new technologies and transfer the knowledge of western production.

Negative attitude of neighboring countries and NATO. 
Based on the short SWOT analysis, it can be concluded that the strengths and opportunities of equipping Air Force and Air Defence with a sophisticated weapon systems of eastern production are far greater than the weaknesses and threats. The biggest problem and impediment to this form of equipping would essentially be the political admission of western countries, primarily the United States, but also the fourth industrial revolution and technological solutions that it carries with it, which includes the possibility of the current blocking of the weapons system by the manufacturer using modern information innovations, which represents the enormous blackmailing potential of the western countries, but also advantage of equipping with weapon systems of eastern production which is based on the fact that Russia and China in the last decades were continuing alliance with the Republic of Serbia (in the most difficult times - wars and sanctions).

\section{ECONOMIC NEUTRALITY OF THE REPUBLIC OF SERBIA AND THE BELT AND ROAD INIATIVE}

The speed of economic growth of the People's Republic of China is intriguing the attention of public all around the world, for the past few years (KankarašPetrović-Stojković 2017; Liu 2017). The aim of the latest project - The Belt and Road Initiative (BRI) is to ensure stable and more balanced economic growth of China, as well as strengthening economic and transport connections with neighbors in Central Asia, Europe, South Asia, Southeast Asia, and Africa.

China is the initiator and leader of connection and co-operation within the Belt and Road initiative, which represents a development opportunity not just for China, but also for over 60 countries that are lined along The New Silk Road. For the Republic of Serbia, and its people, the most important aspect of BRI is The China and the Central and Eastern European Countries' co-operation (CEEC16+1), since Belgrade was chosen to be the centre of Association for co-operation in transport and infrastructure. CEEC is covered by 92 bilateral and international contracts and agreements in different fields, signed by PRC and Serbia appears to be the country with the strongest effort to CEEC project (Xin-Vertes 2017).

Recently conducted research showed that Serbian people believe that the most important China's investment in Serbia by now is privatization of Železara Smederevo by Chinese company China's Hebei Iron \& Steel Group (HBIS Group), and as the most important investment in the future they see modernization and reconstruction of Hungarian-Serbian railway connection in the territory of the Republic of Serbia, which is expected to speed up the transport of Chinese goods from the Chinese-owned Greek port of Piraeus to markets in Central and Eastern Europe (Petrović 2018). Results of this research also shows that young people in Serbia have great expectations from co-operation with People's Republic of China, based on BRI and CEEC, especially in the fields of tourism, 
economy, construction industry and transportation and they are not satisfied with results of co-operation in the fields of security (police and army forces).

That kind of expectations of Serbian public are connected also with one of the frequent meetings of Serbian President and PRC President and signing of numerous, among others RTB Bor - Zijin Mining Group Ltd. and contract of building of fabric with Shandong Linglong Tire Co. Ltd., a Chinese tire manufacturing enterprise in Zrenjanin (Вечерње новостии 2018).

By cooperating with the PRC on projects BRI and CEEC 16+1, Serbia strengthens economics and economic power, which allows a gradual increase in allocations to equip the army with complex combat systems, because the existing systems have run out of resources exploitation. The importance of economic parameters as a condition for membership is also recognized by NATO. Countries that have a high standard of living and a developed economy are more stable in every aspect, and therefore in a security sense. The economy of small countries can directly contribute to improving the security situation, and economic relationships with the world can be used to strengthen friendship and improve relations between countries. Furthermore, if neutral countries want to have an effective foreign policy, they must also have an effective defence system.

\section{CONCLUSION}

Serbian people have great trust in PRC in Chinese people, not only based on expectations of prosperity and benefits of BRI and CEEC but also because of years of effort and mutual understandings. There is no doubt that the opportunities for improving the co-operation between China and Serbia remain high. It should be noted that Serbia and China have similar attitudes to international law, as well as the most important global geopolitical events. Furthermore, the position of China on the issue of Kosovo and Metohija is also clear and explicitly in line with the attitude of the Republic of Serbia, as well as the support of Serbia to the policy of China. Valuation orientation, ideological connection, common anti-globalist struggle, respect for mutual territorial integrity, as well as excellent geostrategic position of the Republic of Serbia on the BRI route create excellent preconditions for further development of affirmative relations in all spheres of social life between China and Serbia.

Condizio sine qua non of this excellent basis is the fact that although China is the initiator and leading force behind the Belt and Road, all the other countries are equal partners, which was not the case through history in treatment of China and its people by other nations for centuries (i.e. colonial period, Opium wars, Japans' invasions, position of Chinese immigrants in US, etc.). This is compatible with concept of neutrality which represents one of the postulates of foreign 
policy of the Republic of Serbia. Serbia is the most active state in the implementation of BRI strategy and projects, despite pressures from non-military institutions like the IMF, where it can be thought about whether it is a type of economic war because it is obvious that international institutions can represent the forces levers of some superpowers in the attempt to discipline insufficiently obedient members and countries, by possessing enormous blackmailing capacities.

However, since the world once again "slides" towards multipolarity, the Republic of Serbia has mechanisms based on friendly relations since the time of the Non-Aligned Movement, which is managed to be maintained in the last twenty years. A firm attitude not to impose economic sanctions on the Russian Federation and stable bilateral relations with China represent a huge capital that Serbia will be able to perform in the future primarily in terms of ensuring energy stability. In the field of military neutrality, it is actively working on equipping with modern weapon systems so that this neutrality can be defended where necessary. A strong defence will also be a guarantor of the stability of the Republic of Serbia and capital investments, which should be more in the future. Bearing in mind that capital investments carry the transfer of technologies and knowledge, from the Republic of Serbia in the future, it should be expected to develop itself into a modern, secure, economically stable and politically independent country of Southeast Europe.

\section{REFERENCES}

Boczek 1989: B. A. Boczek. "Introduction: The Conceptual and Legal Framework of Neutrality and Nonalignment in Europe". In V. S. Papacosma - M. R. Rubin (Eds.). Europe's Neutral and Nonaligned States: Between NATO and the Warsaw pact. Wimmgion, Delaware: SR Books, 1-42.

Bogetić 2013: D. Bogetić. „Jugoslavija i Pokret nesvrstanih“ ["Yogoslavia and Non-aligned Movement”]. U I. Novaković - B. Milinčić - J. Kajganović (Ur.). Neutralnost u XXI veku - pouke za Srbiju, zbornik radova. Beograd: ISAC Fond Centar za međunarodne i bezbednosne poslove, 33-37.

Brkić 2009: L. Brkić. „Troškovi pripreme integracije u NATO - slučaj Hrvatske“ [“Costs of preparing of integration in NATO - Croatian case”]. U M. Hadžić - J. Radoman (ur.). Ekonomija i bezbednost. Beograd: Centar za civilno-vojne odnose, 91-104.

Brunner 2000: H. P. Brunner. "Neutralität der Schweiz: Wie weiter?” Im R. Bernhard, H. P. Brunner, U. Zimmerli - F. Jeanneret (Eds.). Die neutrale Schweiz im Europa-Test, $11-57$.

Вечерње новостии 2018: <http://www.novosti.rs/vesti/naslovna/politika/aktuelno.289. html:749351-UOCI-POSETE-VUCICA-Iz-Kine-stize-tri-milijarde-dolara>. [14. 09. 2018].

Đurašinović-Radojević 2016; Đurašinović - D. Radojević. „Švajcarska oružana neutralnost“ [“Switzerland's armed neutrality”]. U S. T. Korać (ur.). Zbornik radova sa naučne konferencije: Uticaj vojne neutralnosti Srbije na bezbednost $i$ stabilnost u Evropi. Beograd: Institut za međunarodnu politiku i privredu, 52-75. 
Fišer 2013: T. Fišer. „Evropske neutralne zemlje tokom Hladnog rata“ [“European neutral states during the Cold War”]. U I. Novaković, B. Milinčić, J. Kajganović (ur.). Neutralnost u XXI veku - pouke za Srbiju, zbornik radova. Beograd: ISAC Fond Centar za međunarodne i bezbednosne poslove, 27-32.

Gaspar 2007: C. Gaspar. "Portugal, os Pequenos Estados e a Uniao Europea”. Nacao e Defesa, 118(3), 107-145.

Gordić-Petrović 2014: M. Gordić - I. Petrović. Raketni sistemi u odbrani malih država [Anti air craft missile system in the defence of small countries]. Beograd: MC Odbrana.

Grlić-Radman 2003: Grlić - D. Radman. „Neutralnost Švicarske i njezino članstvo u UN“ ["Switzerland's neutrality and its membership in the UN"]. Politička misao: časopis za politologiju, (39)3, 145-162.

Hill-Westbrook 1997: T. Hill - R. Westbrook. "SWOT analysis: it's time for a product recall”. Long range planning, 30(1), 46-52.

Jončić 2016: M. Jončić. „Geneza neutralnosti u izvorima međunarodnog prava“ ["The genesis of neutrality under international law”]. U S. T. Korać (ur.). Zbornik radova sa naučne konferencije: Uticaj vojne neutralnosti Srbije na bezbednost i stabilnost u Evropi. Beograd: Institut za međunarodnu politiku i privredu, 11-28.

Kankaraš-Petrović-Stojković 2017: M. Kankaraš - I. Petrović - B. Stojković. "Opportunities and threats of new idea”. In D. Dimitrijević - H. Ping (Eds). Thematical Proceeding from the International Scientific Conference: Initiatives of the New Silk Road Achievements and Challenges. Belgrade: Institute of International Politics and Economics, 255-266.

Kirijan 2013: J. Kirijan. „NATO i evropske (stalno) neutralne države: Neutralnost ne predstavlja problem za NATO" ["NATO and European (permanent) neutral countries: Neutrality do not represents problem for NATO”]. U I. Novaković - B. Milinčić - J. Kajganović (ur.). Neutralnost u XXI veku - pouke za Srbiju, zbornik radova. Beograd: ISAC Fond Centar za međunarodne i bezbednosne poslove, 81-83.

Krivokapić 1998: B. Krivokapić. Leksikon međunarodnog prava. Beograd: Institut za uporedno pravo.

Litavski 2012: J. Litavski. „Kontroverze vojne neutralnosti Srbije“ [“Controverses of military neutrality of Serbia”]. Novi Vek - tromesečnik Centra za evroatlantske studije. 1-6. <https://www.ceas-serbia.org/images/prilozi/05-1.pdf>. [04. 10. 2018].

Liu 2017: Z. Liu. "The risks assessment of the belt and road initiative in Central and Eastern Europe”. In D. Dimitrijević - H. Ping, H. (Eds). Thematical Proceeding from the International Scientific Conference: Initiatives of the New Silk Road Achievements and Challenges. Belgrade: Institute of International Politics and Economics, 267-277.

Morgenthau 1948: A. H. Morgenthau. The Struggle for Power and Peace. Nova York: Alfred Kopf. Narodna skupština Republike Srbije: Rezolucija o zaštiti suvereniteta, teritorijalnog integriteta i ustavnog poretka Republike Srbije 2007: <http://www.serbianembassy.no/srpski/ ambasadineVesti.html>. [04. 10. 2018].

Novaković 2012: I. Novaković. Neutralnost u Evropi u 21. veku i slučaj Srbije [Neutrality in Europe in XXI century and case of Serbia]. Beograd: ISAC Fond Centar za međunarodne i bezbednosne poslove.

Novaković 2016: I. S. Novaković. „Politika neutralnost u Evropi kao 'cena' za status stalne neutralnosti“ " $" P o l i c y$ of neutrality as a 'price' for the permanent neutrality status"]. U: S. T. Korać (ur.). Zbornik radova sa naučne konferencije: Uticaj vojne neutralnosti Srbije na bezbednost $i$ stabilnost $u$ Evropi. Beograd, Institut za međunarodnu politiku i privredu, 29-51. 
Novaković 2016: I. S. Novaković. Stalno neutralne države u Evropi u posthladnoratovskom periodu (1989-2011) [Permanent neutral states in Europe in Post Cold War period (19892011)]. (Unpublished $\mathrm{PhD}$ thesis, Univerzitet u Beogradu - Fakultet političkih nauka. Beograd, Srbija).

Petrović (in press). J. Petrović. “Attitudes and knowledge of young people in Serbia toward People Republic of China's development”.

Radoman 2016: J. Radoman. Šta je bezbednosna politika Republike Srbije [What is the safety policy of the Republic of Serbia] Beograd: Centar za istraživanje javnih politika. <http:// publicpolicy.rs/publikacije/92c7eacf017cf7a6ed57d9f87fc0af5ba1f02a3e.pdf>. [14. 09. 2018].

Stajić-Radivojević-Mirković2016: Lj. S. Stajić - N. P. Radivojević - V. M. Mirković. „Vojna neutralnost kao princip strateškog opredjeljenja Republike Srbije - problemski pristup" ["Military Neutrality as a Principle of Strategic Orientations of the Republic of Serbia - Problem Solving Approach”]. Зборник раgова Правноі факулиетейа у Новом Cagy, 50(4), 1067-1082.

Štavljanin 2013: D. Štavljanin. „Posthladnoratovske „neutralne“ zemlje - Moldavija, Turkmenistan, Ukrajina" ["Post Cold War neutral countries - Moldova, Turkmenistan, Ukraine”]. U I. Novaković - B. Milinčić - J. Kajganović (ur.). Neutralnost u XXI veku - pouke za Srbiju, zbornik radova. Beograd: ISAC Fond Centar za međunarodne i bezbednosne poslove, 95-101.

Xin-Vertes 2017: C. Xin - A. Vertes. How The CEEC citizens view China's development - based on household survey. China: CEE Institute Nonprofit Ltd.

Wittmann 1998: W. Wittmann. Die Schweiz - Ende eines Mythos. München.

Ziegler 1992: J. Ziegler. Die Schweiz wäscht weisser. München: Droemersche Verlagsanstalt.

Ziegler 1998: J. Ziegler. Die Schweiz, das Gold und die Toten. München: Wilhelm Goldmann Verlag. 


\section{Миодраг А. ГОРАИТ}

Иван Б. ПЕТРОВИТ

\section{МОАЕА ВОЈНЕ НЕУТРААНОСТИ КАО РАЗВОЈНА ПЕРСПЕКТИВА РЕПУБАИКЕ СРБИЈЕ}

\section{САЖЕТАК}

Неутралност, са аспекта одбране земье, примарно подразумева ослањање на сопствене снаге. Војно неутрална земьа не сме бити чиан војног савеза нити учествовати у оружаном сукобу као ратујућа страна, осим ако није у питању самоодбрана, али такође треба Аа промовише и охрабрује мировне процесе. С Аруге стране, политичка неутралност треба Aа искьучи чианство у политичким организацијама које заступају посебне интересе или стварање Аругих формалних политичких савеза који искьучују независно вођење политике земье у питању. Економија малих земаља преко концепта неутралности може Аиректно Аопринети побољшању безбедности, а економски односи са светом се могу користити за јачање пријатељства и побољшање веза међу земьама. Имајући на уму константне промене у међународним односима на глобалном нивбоу, као и сложено безбедносно окружење Републике Србије, војна неутралност са собом носи извесне ризике и преАности. Са тачке гледишта безбедности, Република Србија мора да обезбеди опремање армије модерним системом наоружања у скиаду са безбедносним претњама. То је једини начин Аа она може Аа буде чинимац одвраћања могућих војних претњи, али и гарант неометаног економског развоја земье и заштите виталних економских и инфраструктуралних инвестиција, као преАуслов за економско инвестирање у Републици Србији. С Аруге стране, војна неутралност Републике Србије олакшава ангажовање у значајним пројектима као што су нови „Пут свиме“, који је последица њене неутралности у уским везама између Кине и САА, као главне полуге НАТО-а, али такође и Аругих иницијатива као што је обнавьање сарадње са земьама које су створиме покрет несврстаних. На основу наведеног, извлачи се директан закьучак Аа неутралност као среАство и инструмент политике, преАставња фмексибилну константу спољне политике Републике Србије.

Кьучне речи: BRI, CEEC 16 + 1, Ваздушне снаге и ваздушна одбрана.

Rad je predat 18. marta 2019. godine, a nakon mišljenja recenzenata, odlukom odgovornog urednika Baštine, odobren za štampu. 